Managing Yourself 


\section{ESSENTIALS OF NURSING MANAGEMENT}

Titles in the series

Annabel Broome: Managing Change, 2nd edition

Principles of complex change

Leadership and creating change from within

Imposed to change

The nurse as a change agent

Identifying training and development needs

Appendices

June Girvin: Leadership and Nursing

The development of theories of leadership

Interpretations of leadership

Interpersonal skills and leadership

Leadership and nursing

The story so far...

Traditional attitudes and socialisation

Motivation

Leadership today

Vision - foresight, insight and dreams

Diana Sale: Quality Assurance, 2nd edition

An introduction to quality assurance

Total quality management

Standards of care

Clinical audit

Clinical protocols

Monitoring of providers by purchasers

Verena Tschudin with Jane Schober: Managing Yourself, 2nd edition

'Know thyself'

Valuing yourself

Motivating yourself

Asserting yourself

Stressing yourself

Supporting yourself

Celebrating yourself

Developing yourself and your career 
ESSENTIALS OF NURSING MANAGEMENT

\title{
Managing Yourself
}

\author{
2nd Edition
}

\section{Verena Tschudin}

with Jane Schober

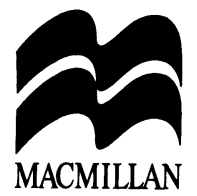


(C) Chapters 1-7, Verena Tschudin; Chapter 8, Jane Schober 1998

All rights reserved. No reproduction, copy or transmission of this publication may be made without written permission.

No paragraph of this publication may be reproduced, copied or transmitted save with written permission or in accordance with the provisions of the Copyright, Designs and Patents Act 1988, or under the terms of any licence permitting limited copying issued by the Copyright Licensing Agency, 90 Tottenham Court Road, London W1P 9HE.

Any person who does any unauthorised act in relation to this publication may be liable to criminal prosecution and civil claims for damages.

The authors have asserted their right to be identified as the authors of this work in accordance with the Copyright, Designs and Patents Act 1988.

First edition 1990

Reprinted three times

Second edition 1998

Published by

MACMILLAN PRESS LTD

Houndmills, Basingstoke, Hampshire RG21 6XS

and London

Companies and representatives

throughout the world

ISBN 978-0-333-73142-0 ISBN 978-1-349-14793-9 (eBook)

DOI 10.1007/978-1-349-14793-9

A catalogue record for this book is available from the British Library.

This book is printed on paper suitable for recycling and made from fully managed and sustained forest sources.

$\begin{array}{llllllllll}10 & 9 & 8 & 7 & 6 & 5 & 4 & 3 & 2 & 1\end{array}$

$\begin{array}{llllllllll}07 & 06 & 05 & 04 & 03 & 02 & 01 & 00 & 99 & 98\end{array}$

Editing and origination by

Aardvark Editorial, Mendham, Suffolk 


\section{Contents}

Acknowledgements vii

Preface viii

$\begin{array}{lll}\text { Chapter } 1 & \text { 'Know thyself' } & 1\end{array}$

Awareness 1

Awareness of the body 2

Awareness of the senses 3

Awareness of the environment 5

Awareness of temperament 6

Awareness of other people $\quad 12$

$\begin{array}{lll}\text { Chapter } 2 & \text { Valuing yourself } & 14\end{array}$

Personal values $\quad 14$

Professional values $\quad 18$

$\begin{array}{lll}\text { Chapter } 3 & \text { Motivating yourself } & 28\end{array}$

Motivation 28

Mistakes and failures $\quad 31$

$\begin{array}{lll}\text { Chapter } 4 & \text { Asserting yourself }\end{array}$

Aggression or assertion? 35

Aspects of behaviour $\quad 38$

Are you assertive? 44

Harassment 46

$\begin{array}{lll}\text { Chapter } 5 & \text { Stressing yourself } & \mathbf{5 0}\end{array}$

Stress and stressors $\quad 50$

Stress $\quad 50$

Stressors $\quad 54$

Coping with stress $\quad 60$ 


\section{Leadership and Nursing}

Chapter 6 Supporting yourself $\quad 66$

Support 66

Professional and practice development $\quad 68$

Preceptors 69

Counsellors $\quad 70$

Support groups $\quad 71$

How are you supporting yourself? $\quad 72$

$\begin{array}{lll}\text { Chapter } 7 & \text { Celebrating yourself } & 77\end{array}$

Celebrating $\quad 77$

Affirming $\quad 77$

Remembering $\quad 81$

Expecting $\quad 83$

$\begin{array}{lll}\text { Chapter } 8 & \text { Developing yourself and your career } & 88\end{array}$

Professional development $\quad 88$

Career pathways in nursing $\quad 94$

Employers of nurses and midwives $\quad 97$

Making the most of career options

and opportunities $\quad 99$

$\begin{array}{ll}\text { Conclusion } & 119\end{array}$

Appendix Careers advice and information useful addresses

Index 


\section{Acknowledgements}

The author would like to thank Jane Schober very particularly for writing the last chapter again. Special thanks go to Richenda Milton-Thompson for her constant help and encouragement with this project.

Every effort has been made to trace all the copyright holders but if any have been inadvertently overlooked the publishers will be pleased to make the necessary arrangement at the first opportunity. 


\section{Preface}

'Management' is one of those words that say very little and imply a great deal. As long as you manage, you're OK.

Management usually means 'other people'. In this book, it means yourself, and this is where the problem starts. We generally know how to manage others. We know what they should do, how they should behave, how they should do their job, look after their children, deal with their colleagues and so on. But to apply these same principles to ourselves is not nearly as easy.

This book starts with the principle that 'charity begins at home'. This does not mean indulging ourselves in all sorts of excess. It means, on the contrary, a kind of discipline that does not shrink away from looking at the good and bad in us, the strengths and weaknesses, the helpful and unhelpful, the possible and impossible parts of ourselves. This can sometimes be daunting. It is not easy to face up to the darker side of the reality that we are, or make choices that lead us into the unknown. However, it is often there that discoveries are made that can and will transform our lives.

As a nurse, you are first of all a person, and although addressed to you as a nurse, this book looks at you as a person. It is meant for you the person, to be more effective in your work as a nurse to manage yourself and others better.

VERENA TSCHUDIN

January 1998 